\title{
Using Basis, Futures Price, and Futures Price Spread as Barometers for Storage Decisions
}

\author{
Mounir Siaplay \\ Department of Economics and Legal Studies in Business \\ Oklahoma State University, United States
}

Brian D. Adam (Corresponding author)

Oklahoma State University

Stillwater, OK 74078, 413 AGH, United States

Tel: 1-405-744-6854 E-mail: Brian.Adam@okstate.edu

B. Wade Brorsen

Regents Professor and Jean \& Patsy Neustadt Chair

Oklahoma State University, United States

Kim B. Anderson

Charles A. Breedlove Professor, Emeritus

Oklahoma State University, United States

Received: February 15, 2012

Accepted: March 6, $2012 \quad$ Published: May 1, 2012

doi:10.5539/ijef.v4n5p15

URL: http://dx.doi.org/10.5539/ijef.v4n5p15

\begin{abstract}
The purpose of this paper is to determine the importance of the strength and weakness of basis, futures spread, and futures prices as barometers for producers to use in deciding whether to store or not. Basis is the most important market signal for wheat producers to use when deciding whether to store and hedge or sell their wheat at harvest.
\end{abstract}

Keywords: Basis, Futures, Storage, Wheat

\section{Introduction}

Every year grain producers and grain elevator managers must decide whether to store grain or sell it at harvest. This decision is complex and it is like a game of chance in which the probability of winning or losing changes each time the game is played (Heifner, 1966). The purpose of this study is to determine the importance of the strength and weakness of basis, futures price, and futures price spread, in predicting returns to storage.

Producers and managers want to know if there are market signals that they can use to a make a harvest time store/sell decision. They desire rules of thumb that can be used to make decisions. Extension economists and market advisors frequently use indicators such as basis, futures prices, and futures price spread as signals for a storage decision. Usset (2009), for example, in the context of a marketing plan for producers, includes those indicators in a marketing decision tree. (Note 1)

Another example of rules of thumb is shown in table 1. The source of this table is unknown, but its author emphasized the use of two of these signals, futures price and basis, in making storage decisions. Some undergraduate agricultural marketing instructors teach their use as well. One textbook, for example, advocates using "basis as a barometer" when making storage decisions (Purcell and Koontz p.32).

From a theoretical perspective, Working (1953) suggested that basis should be a useful indicator of potential returns to storage. In contrast, futures price level is not expected to be a signal since past studies have shown that futures markets are mostly efficient (Kastens and Schroeder, 1996; Tomek, 1997). The empirical research, however, is inconsistent regarding whether basis, futures price spread, and/or futures price level can be used as a signal to store 
or not (Zulauf and Irwin, 1998; Kastens and Dhuyvetter, 1999; Yoon and Brorsen, 2002). Thus, we propose to revisit this issue in the hope of providing a more definitive answer to the empirical question of whether basis, futures price level, and/or futures price spread can serve as a barometer of whether to store or not. This study is quite similar to Zulauf and Irwin (1998) as well as Kastens and Dhuyvetter (1999). However, our regression approach should lead to a more powerful test than the simulation strategies in past research and thus will more clearly measure the usefulness of these signals for storage decisions. Simulation methods are roughly equivalent to regression against a dummy variable of whether or not a signal is above or below a threshold. Such simulation methods may have lower power than the regression approach used here.

In section 2, the theory of the price of storage is presented to provide an understanding of inter-temporal price relationships between spot and futures prices. Theory suggests that futures price level should be a worthless signal, but that the level of basis potentially has value as a storage indicator. Futures price spread is a market indicator of storage returns in that it provides market prices for a commodity to be stored and sold in the future relative to selling it earlier, but little empirical evidence exists to support its usefulness. In section 3, the data used in this study is described; in section 4, the econometric models are presented to measure various returns to storage against measures of the strength and weakness of basis, futures price level, and futures price spread;in section 5, the model misspecification tests are presented to verify that the underlying model assumptions hold; andin sections 6 and 7 results and conclusions are presented.

\section{Theory}

The theory of the price of storage was first proposed by Kaldor (1939) to explain the inter-temporal price relationship between spot and futures prices. Working (1949) viewed the returns to storage as being determined by the supply and demand for storage. Thus when wheat stocks are large, the demand for storage is large and the price of storage is expected to be relatively large. However, if wheat stocks are low, then the economic benefits/returns of storing wheat are small. Furthermore, the theory of the price of storage only holds for highly storable and continuous inventory commodities such as wheat (Brennan, 1958). Over the years, studies on the theory of the price of storage have evolved following Kaldor (1939) including Telser (1958), Williams and Wright (1982), Benirschka and Binkley (1995), and Seamon, Kahl, and Curtis (2001).

The theory of the price of storage includes two different but overlapping views. The first view explains the difference between the spot and futures prices in terms of interest forgone in storing a commodity, physical storage costs, and convenience yield on inventory. This view was shown in the works of Kaldor (1939), Brennan (1958, 1991), and Telser (1958). Under the second view, Cootner (1960), Dusak (1973), Breeden (1980), and Hazuka (1984) show that the theory of the price of storage can be explained by dividing futures prices into an expected risk premium and predicted future spot price (Fama and French, 1987).

Combining these slightly different views, we define the following variables that explain theory of the price of storage. Define $F_{T}$ as the future price for delivery of a commodity and $S_{t}$ as the spot price. The price of storage at time $t$ from holding a commodity until time $T$ is defined as

$$
F_{T}-S_{t}=S_{t} R+W+P-C
$$

Where $R$ is the interest rate, and thus $S_{t} R$ is the opportunity cost of holding stocks, $W$ is physical storage cost, $P$ is risk premium, and $C$ is convenience yield.

The concept of basis is important because it combines both the spot and futures prices, which reflects the current and expected demand and supply conditions, respectively (Leuthold and Peterson, 1983; Purcell and Koontz, 1999). While equation (1) relates the spot and futures prices (the basis), the key question that arises is "what does the theory of the price of storage say about basis and/or futures price as a market signal?" The theory of the price of storage suggests that initial basis can help producers and grain managers decide whether to store or sell their grain at harvest since the spot and futures prices should converge as $t$ approaches $T$. The reliability of this prediction might be affected if physical storage costs (including costs of maintaining quality) or opportunity cost of storing grain change over time, or if risk premium or convenience yield vary, so that the ending basis at time $T$ varies over time. Further, physical storage costs increase depending on the quantity of commodity stored. As more grain needs to be stored, it must be stored in higher cost facilities or locations. Moreover, if convenience yield is high then returns to storage should be low as a signal for grain owners to sell their stocks. A measure that compares the initial basis with expected basis at time $T$ should provide a prediction of returns to storage.

Conversely, although a high futures price indicates that wheat will be valuable later, to the extent futures markets are efficient, that value should already be reflected in current prices so that futures prices cannot be used as a barometer 
by grain owners to decide whether to store or sell their grain. As Kastens and Schroeder (1996) stated, the futures market is expected to be mostly efficient, so futures price level should not help predict price changes. Alternatively, as Yoon and Brorsen (2002) explained, behavioral finance aspects such as overconfidence, anchoring, and regret by grain traders provide a possible theoretical reasoning to argue for mean reversion in futures prices, and thus for futures price level to aid in predictions.

Finally, futures price spread, the difference between the price of a distant contract and the price of a nearby contract, is a market signal of storage returns that some have recommended as a storage signal (see, for example, Usset). To the extent cash prices converge to futures prices at contract expiration, the distant futures price minus the nearby futures price should also provide a prediction of returns to storage.

Therefore, this study generates three testable hypotheses about the theory of the price of storage. First, grain producers and elevator managers can use basis as a market signal to decide whether to store or sell their grain; second, they can use futures price as a market signal to decide whether to store or sell their grain; and third, they can use futures price spread as a market signal to decide whether to store or sell their grain.

\section{Data}

The commodity chosen is Oklahoma wheat. Oklahoma monthly average cash wheat prices are obtained from the National Agricultural Statistics Service (NASS) of the United States Department of Agriculture (NASS/USDA) from 1975-2005. (Note 2) Monthly average Kansas City Board of Trade (KCBT) December wheat contract prices are obtained from the KCBT for the same periods as the monthly average cash wheat price series. The daily commercial storage costs represent the physical cost of storage charged by elevators and the opportunity cost of interest. The commercial grain storage rates were from Oklahoma Grain and Feed Association from 1975-2005. The monthly cost-of-carry loan interest rates were obtained from 1975-2005 Economic Research Service of the United States Department of Agriculture (ERS/USDA). Although an individual producer would find analysis using prices from a particular location more useful than state average prices, the purpose of the paper is to test usefulness of recommended rules of thumb. Using state averages reduces noise in the data, raising the power of the statistical tests.

\section{Econometric Model}

\subsection{Dependent Variables}

The dependent variables considered are gross revenue, net gross revenue, basis change, basis change less cost of carry, and futures price change. It is assumed that a producer choosing to store grain at harvest in June stores until November. Klumpp, Brorsen, and Anderson (2007) note that on average during the years 1991-2001 Oklahoma wheat prices declined after December, so there is little likelihood of profitable storage after then, especially after storage costs are deducted. (In southern Oklahoma the net price declines after September, so a selling date of September is considered as well.)

Gross revenue is defined as the difference between the November and June cash price for each year from $1975-2005 .^{2}$ Mathematically, gross revenue is expressed as

$$
\text { Gross Revenue }=P_{N}^{C}-P_{J}^{C}
$$

where $P_{N}^{C}$ is the November (or September) cash price and $P_{J}^{C}$ is the June cash price. This is the equivalent of a producer's price gain from holding grain in storage, unhedged, until November (or September) rather than selling at harvest in June. Net revenue, where storage costs are deducted from gross revenue, was also considered, but since results using net revenue did not differ from those with gross revenue only results with gross revenue are presented here.

Basis change is the return to hedged storage as in Zulauf and Irwin (1998). It is defined as the difference between November and June monthly average December basis. Mathematically, basis change is expressed as

$$
\text { Basis Change }=\left(P_{N}^{C}-P_{N}^{D F}\right)-\left(P_{J}^{C}-P_{J}^{D F}\right)=B_{N}-B_{J}
$$

where $P_{N}^{C}$ is cash price in November, $P_{N}^{D F}$ is December contract futures price in November, $P_{J}^{C}$ is cash price in June, $P_{J}^{D F}$ is December contract futures price in June, $B_{N}$ is the basis in November, and $B_{J}$ is the basis in June. This is the equivalent of a producer's gain from storing grain at harvest in June, hedging $100 \%$ of it on the December futures contract, and liquidating the hedge in November.

The variable Basis Change less Cost of Carry is basis change minus cost of carry from June through the sale date. This is the equivalent of a producer's gain net of storage cost from holding hedged grain in storage until November rather than selling at harvest in June. 
Futures price change is defined as the difference between November and June monthly average December futures price. Futures price change is expressed as

$$
\text { Futures Price Change }=P_{N}^{D F}-P_{J}^{D F}
$$

where $P_{N}^{D F}$ is the November average futures price for December contract, and $P_{J}^{D F}$ is the June average futures price for the December contract.

\subsection{Independent Variables}

Working (1953) suggested that initial basis could be used to forecast basis convergence. Initial basis is defined as June's observation of cash price minus the December futures contract price. Working's suggestion of using initial basis implicitly assumes that ending basis is approximately the same in every year, so that initial basis would be closely correlated with basis convergence. However, storage costs, transportation costs, and supply/demand fundamentals in the cash market relative to the futures market may have changed over time, affecting expected ending basis Some authors (e.g., Purcell and Koontz, 1999, p.35) have suggested using expected basis convergence as a storage signal. Basis deviation, or expected basis change, is an estimate of the expected amount of basis convergence from June through November, and is considered here as an alternative to Initial Basis. (Note 3) Dhuyvetter (2010) presents crop basis maps of both basis and basis deviation, showing that the two measures can differ over time and across locations. Basis deviation is defined here as June's observation of cash price minus the December futures contract price observed in June $\left(B_{J}\right)$, minus an expectation of the basis in November. Here, that expectation is formed using an average of the previous five years' November observations of cash price less the December futures contract price observed in the same November $\left(B_{\text {NAvg }}\right)$, and is expressed as

$$
\text { BasisDeviation } \left.=B_{J}-B_{N A v g} \text {. (Note } 4\right)
$$

Similarly, futures price deviation is defined as the difference between June's price for the December futures contract $\left(P_{J}^{D F}\right)$ minus the average of the previous five years' November observations of the December futures contract prices $\left(P_{N}^{D F A v g}\right)$, and is expressed as

$$
\text { Futures PriceDeviation }=P_{J}^{D F}-P_{N A v g}^{D F} .
$$

This variable could capture mean reversion in futures prices. Kim, Brorsen, and Anderson (2010) argue that research on profit margin hedging and rollover hedging typically shows larger returns than selling at harvest, but the difference is rarely statistically significant. Thus, there is at least some weak empirical evidence in favor of considering the futures price deviation variable.

Futures price spread is defined as June's price for the December futures contract $\left(P_{J}^{D F u t}\right)$ minus June's price for the July futures contract $\left(P_{J}^{J u l F}\right)$, so that

$$
\text { Futures PriceSpread }=P_{J}^{D F}-P_{J}^{J u l F}
$$

This difference reflects the market-forecasted gross return to storage, in that arbitraging those two contracts (e.g., simultaneously selling a December contract and buying a July futures contract, and then taking delivery on the July futures contract, and then liquidating the hedge as the December contract is nearing expiration) will provide that difference as revenue to the decision maker. This measure is also equivalent to using the harvest basis (July contract in June) to forecast the storage basis, which Taylor, Dhuyvetter, and Kastens (2006) argued provided better forecasts of basis than did moving averages.

The second step is to determine the relationship between the dependent variables (gross revenue, basis change, basis change less storage cost, and futures price change) and independent variables (initial basis or basis deviation, futures price deviation, and futures price spread). This will provide a way to test the hypotheses that grain owners can use basis, futures prices, and futures price spread as market signals to store or sell their wheat at harvest.

Ordinary least squares regression models are developed for each model using data from 1975-2005. Using equations (5), (6), and (7) the dependent variables are each regressed on the independent variables as either

$$
Y_{t}=\gamma_{0}+\gamma_{1} \text { Initial Basis }_{t}+\gamma_{2} \text { Futures Price Deviation }_{t}+\gamma_{3} \text { Futures Price Spread }_{t}+\varepsilon_{t}
$$

or

$$
Y_{t}=\gamma_{0}+\gamma_{1} \text { Basis Deviation }_{t}+\gamma_{2} \text { Futures Price Deviation }_{t}+\gamma_{3} \text { Futures Price Spread }_{t}+\varepsilon_{t}
$$

where $Y_{t}$ is the dependent variable at time $t$ and $\varepsilon_{t}$ is the error term. The regression model presented in equation (8) is applied using basis change as the dependent variable. The regression model presented in equation (9) is 
applied using basis change, basis change less cost of carry, futures price change, and gross revenue as dependent variables.

\section{Model Misspecification Tests}

The third step is to conduct misspecification tests for all the regression models. The misspecification tests conducted are normality, static homoskedasticity, autocorrelation, joint conditional mean, and joint conditional variance (McGuirk, Driscoll, and Alwang, 1993). Each misspecification equation as well as its corresponding null and alternative hypotheses is presented.

The omnibus test $\left(K^{2}\right)$ is used to detect deviation from normality as a result of either skewness or kurtosis. This test and its corresponding null and alternative hypotheses are expressed as

$$
\begin{gathered}
K^{2}=Z^{2}\left(\sqrt{b_{1}}\right)+Z^{2}\left(b_{2}\right) \sim \chi_{2}^{2} \\
\mathrm{H}_{0}=\mu \sim N \Rightarrow \sqrt{b_{1}}=0 \text { and } \mathrm{b}_{2}=3 \\
\mathrm{H}_{a}=\mu \operatorname{not} \sim N \Rightarrow \sqrt{b_{1}} \neq 0 \text { or } \mathrm{b}_{2} \neq 3
\end{gathered}
$$

where $K^{2}$ is the omnibus test statistic, $Z\left(\sqrt{b_{1}}\right)$ represents skewness and is asymptotically standard normal with mean zero and variance one, and $Z\left(b_{2}\right)$ represents kurtosis and is asymptotically standard normal with mean zero and variance one.

The static homoskedasticity test is conducted using regression specification error test Kolmogorov-Gaborpolynomials (KG2).Mathematically, the artificial regression is

$$
\begin{gathered}
\widehat{\varepsilon}_{t}^{2}=\alpha+\Delta^{\prime} \Psi_{t}+v_{t} \\
\mathrm{H}_{0}: \Delta^{\prime}=0 \\
\mathrm{H}_{a}: \Delta^{\prime} \neq 0
\end{gathered}
$$

where $\bar{\varepsilon}_{t}^{2}$ is the predicted error term squared, $\Psi_{t}$ is the KG2 test, and $v_{t}$ is the error term.

The autocorrelation test is conducted with an artificial regression as

$$
\begin{gathered}
\widehat{\varepsilon}_{t}=\beta_{0}{ }_{0} X_{t}+\Lambda^{\prime} \widehat{\varepsilon}_{t-1}+v_{t} \\
\mathrm{H}_{0}: \Lambda^{\prime}=0 \\
\mathrm{H}_{a}: \Lambda^{\prime} \neq 0
\end{gathered}
$$

where $\widehat{\varepsilon}_{t}$ is the predicted error term, $X_{t}$ is the independent variable, $\widehat{\varepsilon}_{t-1}$ is predicted lagged dependent variable, and $v_{t}$ is the error term.

Conditional mean tests are conducted together to test for parameter stability, functional form, and independence. Mathematically, the artificial regression is

$$
\begin{aligned}
& \widehat{\varepsilon}_{t}=\beta_{0}^{\prime} X_{t}+\Gamma_{P}{ }^{\prime} \Psi_{t}^{P}+\Gamma_{F}{ }^{\prime} \Psi_{t}^{F}+\Gamma_{I}{ }^{\prime} \Psi_{t}^{I}+v_{t} \\
& \mathrm{H}_{0}: \Gamma_{P}=\Gamma_{F}=\Gamma_{I}=0 \\
& \mathrm{H}_{a}: \Gamma_{P} \neq 0 \text { or } \Gamma_{F} \neq 0 \text { or } \Gamma_{I} \neq 0
\end{aligned}
$$

where $\widehat{\varepsilon}_{t}$ is the predicted error term, $X_{t}$ is the independent variable, $\Psi_{t}^{P}$ represents the structural change using time trend, $\Psi_{t}^{F}$ represent non-linearity using KG2 test, $\Psi_{t}^{I}$ is the lagged error term, and $v_{t}$ is the error term.

Conditional variance tests are conducted to check for static and dynamic heteroskedasticity. This test is based on the following artificial regression

$$
\begin{gathered}
\widehat{\varepsilon}_{t}^{2}=\Gamma_{P}{ }^{\prime} \Psi_{t}^{P}+\Gamma_{S}{ }^{\prime} \Psi_{t}^{S}+\Gamma_{D}{ }^{\prime} \Psi_{t}^{D}+v_{t} \\
\mathrm{H}_{0}: \Gamma_{P}=\Gamma_{S}=\Gamma_{D}=0 \\
\mathrm{H}_{a}: \Gamma_{P} \neq 0 \text { or } \Gamma_{S} \neq 0 \text { or } \Gamma_{D} \neq 0
\end{gathered}
$$


where $\widehat{\varepsilon}_{t}^{2}$ is the predicted error term square, $\Psi_{t}^{P}$ allows structural change using time trend, $\Psi_{t}^{S}$ allows the static heteroskedasticity using KG2 test, and $\Psi_{t}^{D}$ allows for dynamic heteroskedasticity, and $v_{t}$ is the error term.

In models where the normality assumption is violated, the nonparametric bootstrap method is used. This method does not make any distributional assumption such as normality (Greene, Chapter 16). When the autocorrelation assumption is violated, the model is estimated using maximum likelihood (Gujarati, 1995).

\section{Results}

Tables 2 and 3 report parameter estimates for four different models in which the dependent variables (basis change, basic change less storage cost, futures price change, and gross revenue) are regressed on basis deviation, futures price deviation and futures price spread. A fifth model regresses basis change on initial basis (rather than basis deviation), futures price deviation and futures price spread. The results in table 2assume that grain is stored from harvest until the end of November, and the December contract is used for hedging. The results in table 3 assume that grain is stored from harvest until the end of August, and the September contract is used for hedging. (Note 5)

The regression results indicate that basis deviation is statistically significant in predicting basis change and basis change less storage cost. Initial basis is also statistically significant in predicting basis change. The signs are negative in these cases, indicating that the lower June basis is, or the lower June basis is relative to the expected basis at delivery, the higher is the return to hedged grain. Basis deviation is not significant in predicting futures price change orgross revenue. Neither futures price deviation nor futures price spread is significant in predicting any of the dependent variables. This result is consistent with efficient markets theory, with a statistically more powerful empirical test than some previous approaches have provided.

Zulauf and Irwin (1998) found that basis is a useful signal for hedged storage, but not for unhedged storage. Although our results essentially agree with theirs, our interpretation is slightly different. We argue that basis is a useful indicator whether the grain is hedged or unhedged, but the statistical power of the test is larger with hedged storage.

Although the coefficient on basis deviation is not statistically significant in predicting gross revenue (unhedged storage), the results in table 2 suggest that to the extent that futures prices are efficient, basis deviation is a useful predictor of returns to even unhedged storage. By definition, the dependent variable Basis Change equals Gross Revenue minus Futures Price Change - in other words, Basis Change (return to hedged storage) is equal to the change in cash prices less the change in futures prices. If futures prices are efficient, expected Futures Price Change is zero, and expected basis change (Basis Deviation) predicts an equivalent change in basis (Basis Change) and in Gross Revenue (unhedged return to storage).

Supporting this theoretical argument, in table 2, the coefficient on Basis Deviation in the Basis Change regression $(-0.4182)$ is very near the difference between the coefficients on Basis Deviation in the Gross Revenue and Futures Price Change regressions (- $0.2312-0.20225=-0.4376)$. If the coefficient on Basis Deviation in the Futures Price Change regression were zero, the effect of Basis Deviation on Basis Change would be almost equal to its effect on Gross Revenue. The extra randomness in our gross revenue regression ("unhedged storage" in Zulauf and Irwin (1998)) leads to high variability in returns to storage, so that the insignificance of the basis as a barometer in these regressions is due to this variability ("noise") and not because basis is not a useful indicator.

The explanatory power of the regression using initial basis to predict basis change is slightly higher than that of the regression using basis deviation, for hedging on the December futures contract and liquidating at the end of November. In contrast, for hedging on the September contract and liquidating the hedge at the end of August, the results in table 4 show that the explanatory power of the regression using initial basis is much lower than that using basis deviation, and the coefficient on initial basis is statistically insignificant. For a hedge on the September contract, adjusting for past variation in ending basis added predictability.

Tables 4 and 5 report results of misspecification tests for these models. The misspecification tests employed were: normality test (omnibus test), homoskedasticity test (Harvey and Godfredy LM test), autocorrelation test (Durbin-Watson test), joint conditional mean, and joint conditional variance. The results in tables4and 5 indicate that we reject the null hypothesis of normality for the basis change and basis change less cost of carry models. For these models nonparametric bootstrapping, which does not require normality, was employed.

\section{Conclusions}

The results show that basis is a more consistent market signal than futures price or futures price spread for wheat producers and grain elevator managers to use when deciding to store or sell their wheat at harvest. This finding is important because although the theoretical argument is strong, the empirical research has been more suggestive than 
conclusive. Thus, these results answer our earlier research question, "Are there market signals that grain producers and elevator managers can use to make the harvest store/sell decision?" The answer is "Yes, basis should be used as a market signal by wheat producers and grain elevator managers." For greater assurance, however, in achieving expected returns to storage, the grain should be hedged using the futures market, not just stored.

Earlier research relied on simulation methods that may have lower power than the regression approach used here. The results indicate that basis is the single most important indicator that can affect the decision to store or sell wheat at harvest. The theoretical argument is strong and the empirical research results are strong for using basis as a barometer.

\section{References}

Benirschka, M., \& Binkley, J. (1995). Optimal Storage and Marketing over Space and Time. American Journal of Agricultural Economics, 77, 521-24. http://dx.doi.org/10.2307/1243220

Breeden, D.T. (1980). Consumption Risks in Futures Markets. Journal of Finance, 35, 503-20. http://dx.doi.org/10.2307/2327411

Brennan, M. J. (1958). The Supply of Storage. American Economic Review 48, 50-72.

Cootner, P.H. (1960). Returns to Speculators:Telser vs. Keynes. Journal of PoliticalEconomy, 68, 396-404. http://dx.doi.org/10.1086/258347

Dhuyvetter, K. (2010). Crop Basis Maps. Department of Agricultural Economics, Kansas State University, available at http://agmanager.info/marketing/basis/maps/archives/default.asp.

Dusak, K. (1973). Futures Trading and Investor Returns: An Investigation of Commodity Market Risk Premiums. Journal of Political Economy, 81, 1387-1406. http://dx.doi.org/10.1086/260133

Fama, E.F., \& French, K.R. (1987). Commodity Futures Prices: Some Evidence on Forecast Power, Premiums, and the Theory of Storage. Journal of Business, 60, 55-74. http://dx.doi.org/10.1086/296385

Greene, W.H. (2003). Econometric Analysis, 5th Edition. Upper Saddle River, NJ: Prentice-Hall.

Gujarati, Damodar. (1995). Basic Econometrics, $3^{\text {rd }}$ Edition. McGraw-Hill. New York.

Hatchett, R.B., Brorsen, B.W., \&Anderson, K.B. (2010). Optimal Length of Moving Average to Forecast Basis. Journal of Agricultural and Resource Economics, 35,18-33.

Hazuka, T.B. (1984). Consumption Betas and Backwardation in Commodity Markets. Journal of Finance 39, 647-55. http://dx.doi.org/10.2307/2327923

Heifner, R.G. (1996). The Gains from Basing Grain Storage Decisions on Cash-Future Spreads.Journal of Farm Economics, 1490-1495.

Kaldor, N. (1939). Speculation and Economic Stability. Review of Economic Studies, 7, 1-27. http://dx.doi.org/10.2307/2967593

Kansas City Board of Trade. December Wheat Contract Prices.http://www.KCBT.com/historical_data.asp (accessed May, 2006).

Kastens, T.L., \& Schroeder, T.C. (1996). Efficiency Tests of July Kansas City Wheat Futures. Journal of Agricultural and Resource Economics, 21(2),187-198.

Kastens, T.L., \& Dhuyvetter, K. (1999). Post-harvest Grain Storing and Hedging with Efficient Futures. Journal of Agricultural and Resource Economics, 24(2),482-505.

Kim, H.S., Brorsen, B.W., \& Anderson, K. B. (2010). Profit Margin Hedging. American Journal of Agricultural Economics, 92,638-653. http://dx.doi.org/10.1093/ajae/aap038

Klumpp, J.M., Brorsen, B.W., \& Anderson, K.B. (2007). Returns to Storage: Does Aggregation Matter? Journal of Agricultural and Applied Economics, 39, 571-579.

Leuthold, R.M., \& Peterson, P.E. (1983). The Cash-Futures Price Spread for Live Hogs. North Central Journal of Agricultural Economics, 5, 25-29. http://dx.doi.org/10.2307/1349189

McGuirk, A.M., Driscoll, P., \& Alwang, J. (1993). Misspecification Testing: A Comprehensive Approach. American Journal of Agricultural Economics, 75, 1044-1055. http://dx.doi.org/10.2307/1243992

National Agricultural Statistics Service of the United States Department of Agriculture. (no date) Oklahoma Monthly Average Cash Wheat Prices. (accessed March 29, 2007). 
Oklahoma Grain and Feed Association. (2006). Commercial Grain Storage Rates (private communication).

Purcell, W.D., \& Koontz, S.R. (1999). Agricultural Futures and Options: Principles and Strategies - Second Edition. Upper Saddle River, NJ: Prentice-Hall.

Seamon, V.F., Kahl, K.H., \& Curtis, Jr., C.E. (2001). Regional and Seasonal Differencesin the Cotton Basis. Journal of Agribusiness, 19(2), 147-161.

Taylor, M., Dhuyvetter, K.C., \& Kastens, T.L. (2006). Forecasting Crop Basis Using Historical Averages Supplemented with Current Market Information. Journal of Agricultural and Resource Economics, 31, 549-567.

Telser, L.G. (1958). Futures Trading and the Storage of Cotton and Wheat. Journalof Political Economy, 66, 233-55. http://dx.doi.org/10.1086/258036

Tomek, W.G. (1997). Commodity Futures Prices as Forecasts. Review of Agricultural Economics, 19(1), 23-44. http://dx.doi.org/10.2307/1349677

Usset, Edward. (no date). The Post-Harvest Marketing Challenge" and "Post-Harvest Marketing Plans, videos at http://cornandsoybeandigest.com/consistency_counts_asgrow/, accessed March 2009.

Vocke, G., \& Allen, E. (2006). Wheat Situation and Outlook Yearbook. Economic Research Service, United States Department of Agriculture (accessed May, 2006).

Working, H. (1949). The Theory of Price of Storage. American Economic Review 39, 1254-62.

Working, H. (1953). Hedging Reconsidered. Journal of Farm Economics, 35(4), 544-61. http://dx.doi.org/10.2307/1233368

Wright, B.D., \& Williams, J. C. (1982). The Economic Role of Commodity Storage. The Economic Journal, 596-614. http://dx.doi.org/10.2307/2232552

Yoon, B.S., \& Brorsen, B. W. (2002). Market Inversion in Commodity Futures Prices. Journal of Agricultural and Applied Economics, 34(3), 459-476.

Zulauf, C.R., \& Irwin, S.H. (1998). Market Efficiency and Marketing to Enhance Income of Crop Producers. Review of Agricultural Economics, 20(2), 308-331.

\section{Notes}

Note 1. Usset uses the term "carry charge" for the indicator referred to here as spread.

Note 2. Although an individual producer would find analysis using prices from a particular location more useful than state average prices, the purpose of the paper is to test usefulness of recommended rules of thumb. Using state averages reduces noise in the data, raising the power of the statistical tests.

Note 3. Working (1953) notes that basis by itself is a good predictor of a hedger's profit from storage. Basis deviation as defined here is a similar measure, but may be more useful as a rule of thumb for a hedger since it can be directly interpreted as being high or low whereas initial basis alone still needs a benchmark to compare to in order to reach a decision.

Note 4. Hatchett et al. (2010) found that a 1-yr moving average of previous basis was a slightly better predictor of ending basis than a 3 -yr. or 5-yr. moving average, but in our analysis a five-year moving average performed very slightly better.

Note 5. For storage until September, all November prices are replaced with September prices

Table 1. Pre-harvest Market Signals and Marketing Strategies to Consider

\begin{tabular}{lll}
\hline Market Signal (Basis) & Price & Potential Strategies \\
\hline Weak & Low & Store unhedged \\
Weak & High & Store and hedge \\
Normal & Normal & Stagger sales \\
& & Sell \& buy call option; \\
Strong & Low & Basis contract \\
Strong & High & Sell at harvest \\
\hline
\end{tabular}

Source: Original source is unknown. 
Table 2. Parameter Estimates for Five Models: Storing until November

\begin{tabular}{|c|c|c|c|c|c|}
\hline Variables & $\begin{array}{c}\text { Basis Change } \\
\text { (w/Basis } \\
\left.\text { Deviation }_{t}\right)\end{array}$ & $\begin{array}{c}\text { Basis Change } \\
\left(\mathrm{w} / \text { Initial Basis }_{t}\right)\end{array}$ & $\begin{array}{l}\text { Basis Change } \\
\text { Less Cost of Carry }\end{array}$ & Futures Price Change & Gross Revenue \\
\hline Intercept & $\begin{array}{c}0.1817 \\
(0.2365)\end{array}$ & $\begin{array}{l}-7.3628 \\
(4.8795)\end{array}$ & $\begin{array}{c}0.1363 \\
(0.2390)\end{array}$ & $\begin{array}{c}8.8407 \\
(18.2494)\end{array}$ & $\begin{array}{c}17.3601 \\
(17.9953)\end{array}$ \\
\hline Basis deviation & $\begin{array}{c}-0.4182 * * \\
(0.0030)\end{array}$ & - & $\begin{array}{c}-0.4376^{* *} \\
(0.0015)\end{array}$ & $\begin{array}{l}0.20225 \\
(0.9160)\end{array}$ & $\begin{array}{l}-0.2312 \\
(0.9033)\end{array}$ \\
\hline Initial Basis & - & $\begin{array}{l}-0.5393 * * \\
(0.14662)\end{array}$ & - & - & \\
\hline $\begin{array}{l}\text { Futures price } \\
\text { deviation }\end{array}$ & $\begin{array}{c}0.0217 \\
(0.4165)\end{array}$ & $\begin{array}{c}0.0217 \\
(0.0205)\end{array}$ & $\begin{array}{c}0.0135 \\
(0.3470)\end{array}$ & $\begin{array}{l}-0.1685 \\
(0.1487)\end{array}$ & $\begin{array}{l}-0.1506 \\
(0.1466)\end{array}$ \\
\hline $\begin{array}{l}\text { Futures Price } \\
\text { Spread }\end{array}$ & $\begin{array}{c}0.2578 \\
(0.4480)\end{array}$ & $\begin{array}{c}0.1123 \\
(0.24892)\end{array}$ & $\begin{array}{c}0.1992 \\
(0.3920)\end{array}$ & $\begin{array}{l}-0.2761 \\
(1.7102)\end{array}$ & $\begin{array}{l}-0.0605 \\
(1.6864)\end{array}$ \\
\hline $\mathrm{R}^{2}$ & 0.6029 & 0.6294 & 0.5784 & 0.0539 & 0.0444 \\
\hline
\end{tabular}

Note: P-values are in parentheses under the coefficients for Basis Change(w/Basis Deviation), and Basis Change Less Cost of Carry as these models were re-estimated using a non-parametric bootstrap method because the normality assumption was violated (see Table $4 \& 5$ ). However, standard errors are in parentheses under the coefficients for the Basis Change(w/Initial Basis, Futures Price Change, and Net Revenue models.

** indicates significance at the $5 \%$ level.

Table 3. Parameter Estimates for Dependent Variables Basis Change, Futures Price Change, and Net Revenue (1975-2005): Storing until September

\begin{tabular}{|c|c|c|c|c|c|}
\hline & $\begin{array}{c}\text { Basis Change } \\
(\mathrm{w} / \text { Basis } \\
\left.\text { Deviation }_{t}\right)\end{array}$ & $\begin{array}{c}\text { Basis Change } \\
\left(\mathrm{w} / \text { InitialBasis }_{t}\right)\end{array}$ & $\begin{array}{l}\text { Basis Change } \\
\text { Less Cost of Carry }\end{array}$ & Futures Price Change & Gross Revenue \\
\hline Intercept & $\begin{array}{r}0.0122 \\
(0.2555)\end{array}$ & $\begin{array}{l}-3.6497 \\
(6.1215)\end{array}$ & $\begin{array}{r}0.1869 \\
(0.2305)\end{array}$ & $\begin{array}{r}8.6928 \\
(19.7276)\end{array}$ & $\begin{array}{r}19.3069 \\
(19.4741)\end{array}$ \\
\hline Basis deviation & $\begin{array}{r}-0.3082 * * \\
(0.0115)\end{array}$ & - & $\begin{array}{r}-0.3219 * * \\
(0.0125)\end{array}$ & $\begin{array}{r}0.2293 \\
(0.8465)\end{array}$ & $\begin{array}{r}-0.0866 \\
(0.8355)\end{array}$ \\
\hline Initial Basis & - & $\begin{array}{r}-0.1984 \\
(0.1838)\end{array}$ & - & - & - \\
\hline $\begin{array}{l}\text { Futures price } \\
\text { deviation }\end{array}$ & $\begin{array}{r}0.0163 \\
(0.3825)\end{array}$ & $\begin{array}{r}0.0079 \\
(0.02495)\end{array}$ & $\begin{array}{r}0.0082 \\
(0.3105)\end{array}$ & $\begin{array}{l}-0.1744 \\
(0.1444)\end{array}$ & $\begin{array}{r}-0.1608 \\
(0.1425)\end{array}$ \\
\hline $\begin{array}{l}\text { Futures Price } \\
\text { Spread }\end{array}$ & $\begin{array}{r}0.4502 \\
(0.4865)\end{array}$ & $\begin{array}{r}0.4018 \\
(0.3139)\end{array}$ & $\begin{array}{r}0.3952 \\
(0.4710)\end{array}$ & $\begin{array}{r}-0.3363 \\
(1.6123)\end{array}$ & $\begin{array}{r}0.0675 \\
(1.5916)\end{array}$ \\
\hline $\mathrm{R}^{2}$ & 0.5365 & 0.3414 & 0.5115 & 0.0630 & 0.0515 \\
\hline
\end{tabular}

Note: P-values are in parentheses under the coefficients for Basis Change with Basis Deviation $\left(B D_{t}\right)$, and Basis Change Less Storage Cost as these models were re-estimated using a non-parametric bootstrap method because the normality assumption was violated (see Table $4 \& 5$ ). However, standard errors are in parentheses under the coefficients for the Basis Change with Initial Basis $\left(I B_{t}\right)$, Future Price Change, and Net Revenue models. ** indicates significance at the $5 \%$ level. 
Table 4. Misspecification Tests for Basis Change, Futures Price Change, and Net Revenue (1975-2005):

Storing until November

\begin{tabular}{|c|c|c|c|c|c|}
\hline & $\begin{array}{c}\text { Basis Change } \\
\left(\mathrm{w} / \text { Basis Deviation }_{t}\right)\end{array}$ & $\begin{array}{l}\text { Basis Change } \\
\text { (w/Initial Basist, }\end{array}$ & $\begin{array}{l}\text { Basis Change } \\
\text { Less Cost of Carr }\end{array}$ & Futures Price Change & Gross Revenue \\
\hline $\begin{array}{l}\text { Normality } \\
\text { (Omnibus test) }\end{array}$ & $(0.0682)^{* *}$ & $(0.1562)$ & $(0.0739)^{* *}$ & $(0.5639)$ & $(0.5390)$ \\
\hline $\begin{array}{l}\text { Static Homoskedasticity } \\
\text { (White test) }\end{array}$ & $\begin{array}{r}0.9600 \\
(0.4462)\end{array}$ & $\begin{array}{r}1.0900 \\
(0.3854)\end{array}$ & $\begin{array}{r}1.0900 \\
(0.3869)\end{array}$ & $\begin{array}{r}0.9600 \\
(0.4796)\end{array}$ & $\begin{array}{r}1.0200 \\
(0.4319)\end{array}$ \\
\hline $\begin{array}{l}\text { Autocorrelation } \\
\text { (Durbin-Watson test) }\end{array}$ & $\begin{array}{r}1.8709 \\
(0.2984)\end{array}$ & $\begin{array}{r}1.8914 \\
(0.3391)\end{array}$ & $\begin{array}{r}1.8744 \\
(0.3107)\end{array}$ & $\begin{array}{r}2.2079 \\
(0.6255)\end{array}$ & $\begin{array}{r}2.1574 \\
(0.5712)\end{array}$ \\
\hline Joint Conditional Mean & $\begin{array}{r}1.0800 \\
(0.4077)\end{array}$ & $\begin{array}{r}1.2200 \\
(0.3374)\end{array}$ & $\begin{array}{r}1.2400 \\
(0.3290)\end{array}$ & $\begin{array}{r}1.1900 \\
(0.4797)\end{array}$ & $\begin{array}{r}0.2500 \\
(0.9346)\end{array}$ \\
\hline Joint Conditional Variance & $\begin{array}{r}1.5000 \\
(0.2396)\end{array}$ & $\begin{array}{r}1.2400 \\
(0.3270)\end{array}$ & $\begin{array}{r}1.3000 \\
(0.3004)\end{array}$ & $\begin{array}{r}1.1200 \\
(0.5020)\end{array}$ & $\begin{array}{r}0.9200 \\
(0.5493)\end{array}$ \\
\hline
\end{tabular}

Note: For static homoskedasticity, joint conditional mean, and joint conditional variance tests the $F$ critical value is presented with the $p$-value in parentheses. For the autocorrelation and normality tests the $p$-value is in parentheses. ** indicates significance at the $5 \%$ level.

Table 5. Misspecification Tests for Basis Change, Futures Price Change, and Net Revenue (1975-2005):

Storing until September

\begin{tabular}{|c|c|c|c|c|c|}
\hline & $\begin{array}{c}\text { Basis Change } \\
\left(\mathrm{w} / \text { Basis Deviation }_{t}\right)\end{array}$ & $\begin{array}{c}\text { Basis Change } \\
\text { (w/Initial } \\
\left.\text { Basis }_{t}\right)\end{array}$ & $\begin{array}{c}\text { Basis Change } \\
\text { Less Cost of } \\
\text { Carry }\end{array}$ & $\begin{array}{c}\text { Futures Price } \\
\text { Change }\end{array}$ & Gross Revenue \\
\hline $\begin{array}{l}\text { Normality } \\
\text { (Omnibus test) }\end{array}$ & $(0.0298)^{* *}$ & $(0.2270)$ & $(0.0360)^{* *}$ & $(0.6333)$ & $(0.6613)$ \\
\hline $\begin{array}{l}\text { Static Homoskedasticity } \\
\text { (White test) }\end{array}$ & $\begin{array}{r}1.1400 \\
(0.3613)\end{array}$ & $\begin{array}{r}0.9500 \\
(0.4542)\end{array}$ & $\begin{array}{r}1.1900 \\
(0.3426)\end{array}$ & $\begin{array}{r}0.9200 \\
(0.4988)\end{array}$ & $\begin{array}{r}2.1700 \\
(0.1261)\end{array}$ \\
\hline $\begin{array}{l}\text { Autocorrelation } \\
\text { (Durbin-Watson test) }\end{array}$ & $\begin{array}{r}1.8581 \\
(0.2951)\end{array}$ & $\begin{array}{r}1.7633 \\
(0.1883)\end{array}$ & $\begin{array}{r}1.8690 \\
(0.3135)\end{array}$ & $\begin{array}{r}2.2010 \\
(0.6120)\end{array}$ & $\begin{array}{r}2.1682 \\
(0.5766)\end{array}$ \\
\hline Joint Conditional Mean & $\begin{array}{r}1.3200 \\
(0.2931)\end{array}$ & $\begin{array}{r}0.8500 \\
(0.5438)\end{array}$ & $\begin{array}{r}1.5200 \\
(0.2218)\end{array}$ & $\begin{array}{r}2.2100 \\
(0.2756)\end{array}$ & $\begin{array}{r}3.0000 \\
(0.1535)\end{array}$ \\
\hline Joint Conditional Variance & $\begin{array}{r}1.1300 \\
(0.3824)\end{array}$ & $\begin{array}{r}0.6800 \\
(0.6642)\end{array}$ & $\begin{array}{r}1.0200 \\
(0.4416)\end{array}$ & $\begin{array}{r}3.0000 \\
(0.2711)\end{array}$ & $\begin{array}{r}3.8700 \\
(0.1470)\end{array}$ \\
\hline
\end{tabular}

Note: For static homoskedasticity, joint conditional mean, and joint conditional variance tests the $F$ critical value is presented with the $p$-value in parentheses. For the autocorrelation and normality tests the $p$-value is in parentheses. ** indicates significance at the $5 \%$ level. 